
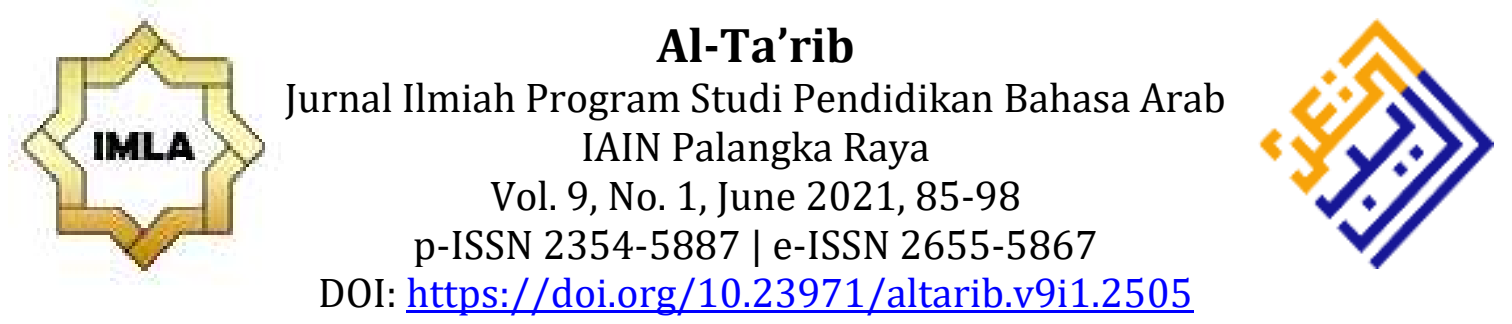

\title{
ONLINE-BASED ARABIC LEARNING MANAGEMENT DURING THE COVID-19 PANDEMIC ERA: PLAN, IMPLEMENTATION AND EVALUATION
}

\author{
Muhyidin Yahya ${ }^{1}$, Maftuhati ${ }^{2}$, Abdul Hayyi Mustofa ${ }^{3}$ Zakiyah Arifa4 \\ 1,2,3,4Universitas Islam Negeri Maulana Malik Ibrahim Malang, Indonesia \\ e-mail: muhyidinyahya97@gmail.com
}

\begin{abstract}
Currently, Arabic language learning is required to be held online. In this situation, the government has forced to announce instructions for implementing online learning since March 2020. However, these instructions have made Arabic teachers experiencing difficulties in implementing online learning. Innovative learning management is highly needed to overcome these problems. Therefore, this study aims to provide an overview of the management of Arabic language learning, especially in planning, implementing, and evaluating, organized by teachers who are members of the Arabic teachers' forum. This study used a descriptive method by adopting data analysis techniques from Miles and Huberman. The results of this study indicate that in planning, the Arabic teachers made a lesson plan which would be held online. As for implementing the lesson plan, the teachers use synchronous and asynchronous models. They also used a combination of two models, a written test presented using Google form and Quizizz media for evaluation. On the other hand, some teachers also conducted oral tests using voice recordings through WhatsApp. This research suggests that teachers can better manage the planning, implementing, and evaluating online learning in the era of the COVID-19 pandemic following the characteristics and models of online learning.
\end{abstract}

Keywords: Arabic; Covid-19; Learning Management; Online Learning

\section{Abstrak}

Saat ini, pembelajaran Bahasa Arab wajib diselenggarakan secara online. Situasi ini memaksa para pemerintah untuk mengumumkan instruksi pemberlakukan pembelajaran online sejak bulan Maret 2020. Namun, intruksi tersebut faktanya justru membuat para guru bahasa Arab mengalami kesulitan dalam menerapkan pembelajaran online. Manajemen pembelajaran inovatif sangat diperlukan untuk mengatasi problematika tersebut. Maka dari itu, penelitian ini bertujuan untuk memberikan gambaran tentang manajemen pembelajaran Bahasa Arab khususnya pada aspek perencanaan, implementasi, dan evaluasi yang diselenggarakan oleh guru yang tergabung dalam forum MGMP bahasa Arab. Penelitian ini menggunakan metode deskriptif dengan mengadopsi teknik analisis data dari Miles and Huberman. Hasil penelitian ini menunjukkan bahwa dalam perencanaan, guru membuat rencana pelaksanaan pembelajaran (RPP) yang akan diselenggarakan secara online. Adapun pada aspek implementasinya, guru bahasa Arab menggunakan model 
sinkronus, dan asinkronus. Di sisi lain, guru bahasa Arab juga menggunakan kombinasi dari kedua model tersebut. Adapun pada aspek evaluasi, guru menggunakan tes tertulis yang disajikan menggunakan media Google form dan Quizizz. Di sisi lain, beberapa guru juga melakukan evaluasi secara lisan menggunakan rekaman suara yang tersedia di media whatsapp. Penelitian ini menyarankan agar para guru lebih baik dalam mengelola perencanaan, proses, dan evaluasi pembelajaran online pada era pandemi COVID-19 yang sesuai dengan karakteristik dan model pembelajaran online.

Kata Kunci: Bahasa Arab; Covid-19; Manajemen Pembelajaran; Pembelajaran Online.

\section{Introduction}

The spread of Corona Virus Disease or COVID-19 presents enormous problems and challenges for Indonesian National Education where the government encourages social distancing and physical distancing to avoid the spread of COVID19, which has been increasingly widespread in Indonesia. Likewise, teaching and learning activities cannot be carried out with a face-to-face model. It means that educational institutions are prohibited from making direct interactions between teachers and students in the classroom. Through Ministry of Education and Culture, the government issued a policy in a circular regarding the implementation of learning in this pandemic situation which states that teaching and learning activities must be applied with distance learning or online learning. Therefore, educational institutions must follow up on Ministry of Education and Culture's policy (Susanto et al., 2020; Widiasih et al., 2020).

Online learning is a part of distance learning and both have the same characteristics, where teachers and students are in different locations and times and use various teaching materials (Corbera et al., 2020; Moore et al., 2011). However, online learning has more specific features, more complex material management, and broader range and flexibility in time and place. The communication is more intense both in real time (synchronous) and non-real time (asynchronous). Many variations of interactive learning methods are used to facilitate processing, updating, and informing learning data (Agustina, 2013). From these features, students can access learning material anytime repetitively and communicate with educators anytime so that students can further strengthen their mastery of learning material. It becomes easier for teachers to upgrade and manage teaching materials following scientific and technological developments happening. The teachers can carry out self-development, even research to increase teacher insight. Learning activities with students can be more easily controlled by processing and analyzing learning data as evaluation material.

The advantages of online learning provide opportunities and benefits for educational development with a technological approach in industrial education 4.0 and apply an open learning style to improve student abilities in academics, life skills, collaboration, creativity and critical thinking (Lase, 2019). Online learning is open and disseminates the learning system using pedagogical tools or so-called teaching aids. It is possible to simplify and shape the learning process and knowledge through internet-based technology and meaningful actions and interactions (Atsani, 2020). It makes distance learning and online learning the 
right solutions to prevent the spread of COVID-19. Also, government policies allow educators to be more innovative in developing more combinations of online learning based on technological developments in the era of the industrial revolution 4.0. Mixing online learning and teaching in the industrial revolution 4.0 requires good and on-target learning management. Learning and teaching require the role of the teacher as a learning designer to provide learners with new and exciting experiences. There are at least three steps in designing a learning activity; planning, implementing, and evaluating (Ernawati \& Mulyono, 2017).

The first step in designing a learning activity is planning. Planning is designing and using available resources to support activities to achieve specific goals effectively (Tamaji, 2018). Arabic learning planning is making learning tools starting from preparing learning materials to determining the media, approaches, methods, strategies, and learning assessments. Teachers must consider three essential things in designing and implementing online learning: what content or learning material the teacher will provide to students; who will receive the learning material by looking at the profile, condition, and need of students; and how to deliver and apply the material (P3GTK Kemendikbud, 2020).

The second step is implementing. Implementation is the core stage in learning activities where the teacher delivers learning material to students to achieve learning objectives. Implementing learning is an interaction between teachers and students in teaching and learning activities. There are three stages of learning Arabic: the pre-instructional stage, the learning stage, and the postlearning stage. The pre-instructional stage is an opening activity in the learning process that contains the classroom atmosphere, student conditions, and material, and followed by the learning stage where activities are done to deliver learning material (Wahid, 2018). The post-learning stage is the last activity in the learning process, consisting of conclusions about the material.

The third step is evaluating. Evaluation is an activity to find out students' understanding of Arabic learning materials and to know to what extent the learning process helps students understand Arabic learning materials (Ridho, 2018). Evaluation of students' Arabic learning outcomes is conducted through formative and summative tests (Fitrianti, 2018), while the learning evaluation process is an assessment of learning design, implementation, and learning outcomes (Gunawan, 2011).

Previous researchers have conducted many types of research on online learning in the aspects of theory, implementation, and development of online learning models. There are recommendations for Smart Education Courses based on blockchain technology to handle the courses' digitalization (Agustin et al., 2020). In theory and implementation, it is recommended to describe learning theoretically and apply variations of distance learning (Suryati, 2017), describe the management of Arabic learning based on blended learning (Noval \& Nuryani, 2020), and review learning designs through Google Classroom (Octaberlina \& Muslimin, 2020; Rozak \& Albantani, 2018) and Whatsapp (Ilmiani et al., 2020; Riqza \& Muassomah, 2020).

In several studies examining the management of online Arabic learning, researchers concluded that previous studies focused on cases in a local scope. Reflecting on this gap, the need to conduct further research related to how Arabic 
language teachers is needed, especially in managing distance learning that has been done for almost a year. Generally, this study describes the implementation of online Arabic learning. Specifically, this study aims to: (a) know the planning of learning Arabic online, (b) know the implementation of online Arabic learning (c) and know the evaluation of online Arabic learning.

\section{Method}

This study used a descriptive method combined with a qualitative approach because this study aims to describe the actual activities concerning the management of Arabic online learning systematically and accurately. This study used an open questionnaire, interview, and documentation to conduct data retrieval. The questionnaire contained questions relating to informant profiles, planning management, implementation, and online-based learning assessments distributed to all informants using Google Form. The interview used was a combination of open and structured interview conducted online through WhatsApp application and the documentation was done by collecting lesson plans and examination (Gibson, 2020).

This research was conducted in November 2020 with 33 informants of Arabic language teachers incorporated in the Arabic teacher forum in Indonesia. Data verification used source triangulation and data collection techniques. In source triangulation, we compared information between Arabic teachers and data collection techniques from questionnaire, interview, and documentation. Data analysis techniques used Miles \& Huberman procedures including data reduction, data display, conclusions, and verification (Miles et al., 2019). Data reduction was begun by collecting polling and interview data, then grouping the data according to the specified categories. The data display was done by making a chart about the profile of informants, both location and level of education, then composing the narrative of the reduced data. From the results of the data display, the management of Arabic learning online can be concluded.

\section{Result and Discussion}

Based on the results of the questionnaire with Arabic teachers who are members of Arabic teachers' forum, there were a total of 33 Arabic teachers from various regions: eight from West Java, eight from East Java, seven from Central Java, two from DKI Jakarta, two from West Sumatera, one from Central Sulawesi, one from South Sulawesi, one from Papua, one from West Papua, one from Gorontalo, one from Aceh, and one from East Kalimantan. Based on the school level, we found that two informants taught in elementary schools, 11 informants taught in junior high school, and 18 informants taught in senior high school. The information detail can be seen in the chart below. 


\section{Chart.1:}

\section{Informants' Location and Level of School}

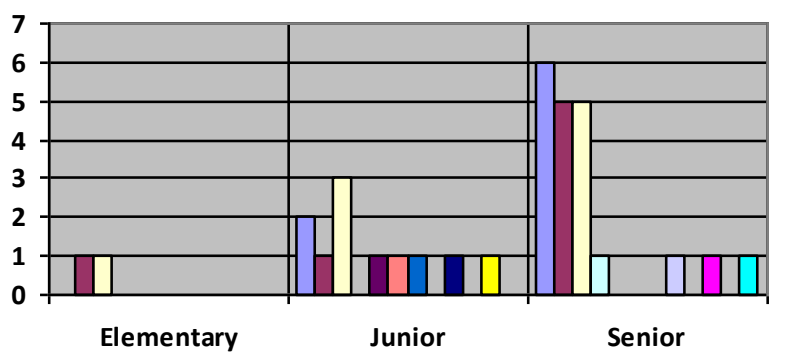

\begin{tabular}{|l|}
\hline$\square$ West Jawa \\
$\square$ Central Jawa \\
$\square$ East Jawa \\
$\square$ Central Sulawesi \\
$\square$ South Sulawesi \\
$\square$ Papua \\
$\square$ West Papua \\
$\square$ Gorontalo \\
Aceh \\
West Sumatera \\
East Kalimantan \\
DKI Jakarta \\
\hline
\end{tabular}

The following is the management of online Arabic learning carried out by Arabic teachers.

\section{Planning}

Online learning plans carried out by Arabic teachers in three steps. The first one is compiling Online-Based Learning Plans (RPP). It was discovered that twenty-eight Arabic teachers made online learning plans, and five teachers did not make online-based learning plans or used offline planning. Based on the questionnaire, most teachers make lesson planning online, and Arabic learning needs this activity as a guideline. The teachers used an online lesson plan based on Ministry of Education and Culture's recommendation called the lesson plan of learning freedom or one-paper lesson plan. The learning plan contains only three components: learning objectives, learning steps, and learning assessments. After planning is preparing the subject, using teaching media, using teaching approaches and methods, and assessing to achieve predetermined goals at a specific time (Yuliani et al., 2020). It is not much different from online learning planning, which includes the design of teaching strategies, communication rules, tools, solutions, and policies that support online or mixed learning in the school community (House et al., 2020). The most crucial matter in an online learning plan is that the teachers must make plans as simple as possible and have clear goals, steps, and assignments for students, teachers, and parents.

The second step in planning is using an online application. From the results of the questionnaire, most Arabic teachers use WhatsApp, with a total of twentyfour teachers. The second most used application is Google Classroom with eighteen teachers. Zoom and Kahoot applications are used by seven teachers, respectively. Nine teachers use e-learning with various models, such as web-based learning and learning management system. Four teachers use Google Meet, and one teacher use the other applications, such as quizzes and YouTube. The user application chart can be seen below. 
Chart. 2:

Learning Application

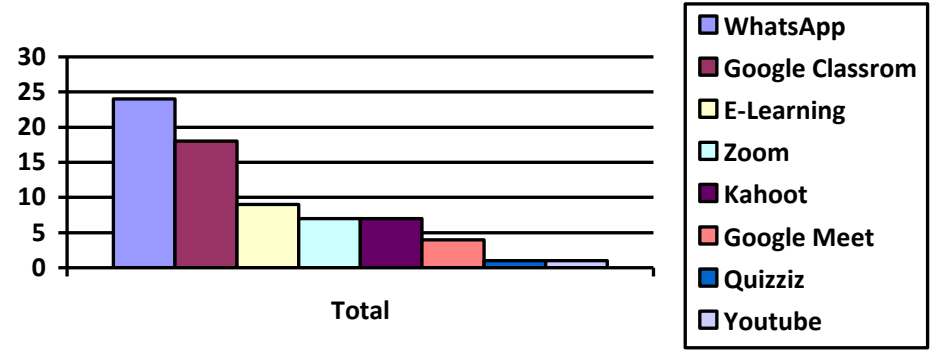

Teachers use various applications in Arabic lesson plans to help the learning process available in their environment, such as chatting room, virtual conference, and e-learning with diverse models based on applications or websites with government or individual support. Some teachers use only one application like WhatsApp or e-learning, and others use two or more applications. In determining the use of this type of application, the teacher considers the aspects of learning needs and the infrastructures belong to all students. It is aligned with Mr. AR's statement, "Using an application for Arabic learning must adapt to students' and teachers' facilities so that learning can run well". All teachers agree with Mr. AR's statement, and the data showed that the Arabic teachers initially conducted needs analysis in designing the lesson plan. In line with what Trisiana and Wartoyo said, identifying learning needs and analyzing learning in learning system design are the first important steps in designing learning activities (Trisiana \& Wartoyo, 2016). Mishra et al. also state, "The teachers and students can use applications as needed well" (Mishra et al., 2020). It will be supported by paying attention to the convenience of access and use of flexible online learning materials and autonomous and innovative learning styles (Sewang, 2017).

The last step is drawing conclusion from the result of the questionnaire. The teachers used the technology on preparing materials, such as videos, slides, and ebooks to facilitate the delivery of materials and access for students and compiled online-based learning materials with various forms of materials like videos, PPT, Pdf, Word, and picture. However, from the documentation, we found that some teachers just moved the book material to a digital platform because they have not much time to design material fast. According to Mrs. SR, "I do not make material for online learning, I just give the student what is in the book because this situation is so sudden". It is compatible with online planning in that the teachers must compile the material in various forms, and the teachers' creativity is needed to summarize and select the material according to the students' needs. Viewed from the main objectives of online learning, the most important thing is to facilitate learning activities and create a learner's learning experiences (Yazdi, 2012). Arranging online learning materials should be simple to make students active and have a pleasant learning experience.

\section{Implementation of Learning}

Implementing online Arabic learning as conducted by Arabic teachers can be done in three steps. The first is the management of online classes. The results of data collection, the researcher found that teachers made rules about online learning, including doing online attendance by filling out attendance 
through Google-Form, WhatsApp, e-learning, and comments. Then, the rules provoke the student's activeness and focus on learning, such as not doing another activity, listening to instructional videos, taking part in giving a question and answer, turning on the cameras, wearing neat school uniforms, and being discipline during the learning and teaching process according to the school schedule. However, some teachers do not require face-to-face virtual classes if they are still on the same day. There is a rule for the collecting assignments, where some teachers do not give the limited-time section, but some do. Mr. A's statement agrees with the former, "Task collection is not limited by time." However, other teachers give a limited time on collecting tasks, like collecting it on the same day or according to lesson schedule. Mrs. N said, "Collecting task at 08.00 p.m. maximum, and other teachers said the assignments task could be collected according to the lesson schedule.

The second is how to deliver the material. Based on the data, the teacher gave the material in various ways, including conferences, timelines, and chats as said by Mrs. L, "I deliver the materials through conferences on e-learning, send information or learning steps to the timeline and add explanations through WhatsApp group." There are also those who use Voice Notes, summaries and learning videos as done by Mr. AR, "I deliver materials by utilizing the media to make explanatory videos and distribute text materials from e-learning applications".

The third is finding the obstacles faced by Arabic teachers during online learning, which usually stem from learning facilities such as quota limitations, internet networks, and devices. Mrs. NU said, "Most students do not have smartphones (HP), so they use their parents' smartphones which also have limited quota. Some students and parents do not even have smartphones at all. Students are simply absent and are lazy to do online tasks." Another opinion expressed by Mrs. NA, "Many children are less focused on learning, do not understand well because of the large number of materials that must be studied personally." Meanwhile, according to Mrs. AS, the obstacles faced are "It is lack of awareness from parents towards children's learning so that children are less able to follow online learning and have limited facilities in online learning".

Implementing learning is a core activity in the teaching and learning activities that require teachers and students to interact well so that the students can accept and understand the teacher's presentation well. In online Arabic learning, two types of interaction between teachers and students found in learning activities are indirect interactions and a combination of direct and indirect interactions. The teacher carries out the indirect interaction by sending steps, objectives, and learning materials as writing or links to class groups. It is consistent with the asynchronous learning model that involves separation in time and space, where students accept the materials via the internet, video satellites, or letters. Students can review the material and communicate with instructors and other students as they wish (Madden, 2016).

In the combination of direct and indirect interaction in online learning, the teacher sends material or assignments as files, pictures, or videos to the class group. On the next meeting, the teacher provides feedback via video conference. Alternatively, the learning begins with the delivery of material and direction via video conference, after that the teacher gives self-assignments in class groups. This 
result showed that the teacher used an asynchronous learning model in the delivery of material where the teacher and students interacted directly at the same time online (Fahmi, 2020). Meanwhile, the assignment uses the asynchronous model by providing a link to each task. The students must do it, but they can also communicate outside the learning schedule with the teacher. In online learning, there are three stages in implementing learning, as offline learning. That is the preinstructional, instructional, and post-instructional stages. According to learning implementation theory, three steps in the learning activities; the pre-instructional step, the learning step, and the post-learning step (Ridho, 2018).

\section{Evaluation of learning}

Evaluation of online-based Arabic learning carried out by Arabic teachers is explained in three points. First, from the data found in online learning assessment outcomes, twelve Arabic language teachers have conducted evaluations by giving written tests, as expressed by Mrs. H, "I often use Google Forms to test the student understanding of the material." Mrs. HF supported this opinion as she said, "I do daily assessment tests using Quizizz application". Some teachers used online tests (CBT). Ten teachers gave assignments, as expressed by Mr. AF, "Learning assessment outcomes is done by looking at the results the students' assignments". Agreeing with him, Mr. S said, "Assignment collection is done via WhatsApp or video". Five teachers gave assignments and tests to assess online learning outcomes. As in evaluating the learning outcomes, Mrs. AF gave instructions in Google Classroom to create a video. The students collected video conversations via email or Instagram and the video was edited as if the students were doing face to face conversation. One teacher gave spoken and written tests, as revealed by Mrs. AZ that the evaluation of learning results was collected by doing written tests and Q\&A during video conferences. Another teacher gave a spoken test, as explained by Mr. DD that he gave a retesting conversation. Another one gave spoken test and assignments. Mrs. SR assessed learning outcomes by conducting direct questions and answers via WhatsApp chat room, performing drills, and reading voice notes to determine students' reading skills. To sum things up, teachers evaluated learning outcomes in two ways: using formative evaluations such as questions and answers when conducting video conferences or giving assignments via google form, voice notes, and quizzes through Quizizz application.

It can be concluded from the results above that the teachers conducted traditional and authentic assessments using test and non-test techniques. The traditional assessment aims to determine students' knowledge in understanding learning material (Nurgiyantoro, 2011), and the teachers do this by giving questions to students in the form of written tests using Google form and Quizizz. The authentic assessment aims to determine students' mastery of knowledge and skills (Nurgiyantoro, 2011). The teachers apply interviews and demonstrations in authentic assessment, whereas other teachers use summative evaluations, such as multiple-choice tests via Google Form, CBT, or file-sending via WhatsApp. In short, Arabic teachers use summative evaluation instruments that focus only on written or traditional assessments. The traditional assessment aims to determine student knowledge competencies from all the material taught during one semester. If the teachers combine several evaluation forms such as spoken assessments, performance appraisals, project appraisals, or product assessments to measure 
language skills, it will be all the better. According to Anderson, it is crucial in online learning assessment to create a "blend" of tasks that cover various dimensions of learning (Anderson, 2011).

Second, from the evaluation of online learning process conducted by Arabic teachers, it was found that twelve teachers used result learning. According to Mrs. MR, it was necessary to evaluate the learning process by looking at the students' average daily test results. Six teachers used student and parent responses, as expressed by Mrs. AS that learning process evaluation was done by using the students and parents' questionnaire results. Moreover, Mrs. HS said that "The evaluation of process learning is done by asking the students directly." Five teachers used observations of student attitudes and attendance. According to Mrs. M, "Evaluating the learning process is done by looking at the activeness and presence of the students." Three teachers used learning outcomes and observations, as explained by Mrs. $\mathrm{N}$ that the students learning results were taken from their activeness, enthusiasm, and participation during learning. Another teacher used the learning result and student response, as done by Mr. MR. He said learning process was tested with daily assessment and questionnaires. Moreover, one teacher used students' response and observation, as mentioned by Mrs. SR. She said learning process was tested daily by asking the students about the obstacles faced when learning and paying attention to student activity through information in chatting.

The teachers evaluate the online learning process by observing when learning takes place, giving questionnaires to students and parents, and doing direct interviews with students related to the previous materials. The teachers apply formative evaluation in evaluating the learning process with observation techniques towards student responses and attitudes. Students' attitudes and enthusiasm during teaching and learning are the criteria for the success of a learning process. In the 21st century, learning must improve student skills. In that case, teachers must be able to update the quality of learning, help students develop participation, adapt learning personalization, emphasize project or problem-based learning, encourage collaboration and communication, increase student engagement and motivation, cultivate creativity and innovation in learning, using appropriate learning tools, and designing learning activities that are relevant to the real world, empower metacognition, and develop student-centered learning (Zubaidah, 2016).

From these indicators, observation is one of the proper techniques to determine the learning activities' process. Apart from formative evaluation, the teachers also implement a summative evaluation, which means the teachers evaluate the process in one semester. The techniques used by the teacher are interviews, questionnaires, and test results. The teachers use questionnaires and interviews to reveal students' responses, expectations, and constraints which are summative evaluations of the learning process from a qualitative point of view. Meanwhile, from a quantitative perspective, the results can be seen from student learning outcomes, whether overall student learning outcomes have reached minimum mastery criteria or not. The achievement of minimum mastery criteria shows that the learning process that has been going on runs smoothly and successfully. 
The third point is the follow-up done by the teacher when finding students who have not reached Minimum Mastery Criteria (Kriteria Ketuntasan Minimal/KKM). Based on the data, 25 teachers gave the failing students remedial. As Mrs. SR said, she arranged a remedial by giving assignments to provide students understanding of the material even though it was simple. Six teachers did a review of the material, as expressed by Mrs. LA that coordination with parents and students could provide some missing materials. She also provided additional teaching through personal chatting, gave additional time to complete the task, and monitored the process with the parents. Another teacher did a material review and remedial. Mr. AR said, "Follow-up activities are done by repeating the delivery of the material if the classical learning method is less than the minimum mastery criteria (KKM), and there is a remedial for individuals that have not reached KKM".

In conclusion, the teachers do various ways according to student needs. These methods include making improvements by providing additional assignments, completing missing assignments, reviewing materials that students have not understood, and providing additional classes for individuals or groups online and offline (if possible) according to the level of difficulty of students. These steps are following the objectives of remedies to heal, correct, or make the teaching system better to achieve optimal learning goals. Remedial activities are a form of handling student learning difficulties and providing guidance, counseling, and psychotherapy to students (Fatayah, 2019).

\section{Conclusion}

The management of online Arabic learning in COVID-19 pandemic meets the distance learning characteristics, as the teachers apply synchronous and asynchronous learning models. However, not all regions can use high-tech media such as Zoom, Google Meet, and e-learning platforms due to limited facilities and infrastructure. Nevertheless, the teachers can manage or organize learning with the facts and needs of students, so that all students can follow the teaching and learning process very well.

Online learning is considered new in Indonesia. Many obstacles require improvement and development to produce better learning and teaching quality in the future. It is suggested for the teachers to manage online Arabic learning to, first, conduct online learning by planning. The teachers provide a role for parents and students in determining the form of activities and the devices used. Involving the environment around students in preparing materials is also crucial because it will be easy and familiar for the students to understand. Second, in conducting online learning implementation, involving students in preparing regulations can be done by appointing them as moderators at each meeting, sharing the materials in groups to avoid misunderstanding, and facilitating supervision for students' abilities. Third, in conducting online learning evaluations, teachers can use students' creativity to produce product tasks and projects.

\section{Reference}

Agustin, F., Oganda, F. P., Lutfiani, N., \& Harahap, E. P. (2020). Manajemen Pembelajaran Daring Menggunakan Education Smart Courses. Technomedia Journal, 5(1), 40-53. https://doi.org/10.33050/tmj.v5i1.1315 
Agustina, M. (2013). Pemanfaatan E-Learning sebagai Media Pembelajaran. Seminar Nasional Aplikasi Teknologi Informasi (SNATI), 1(1).

Anderson, T. (2011). Teaching in an Online Learning Context. In T. Anderson (Ed.), Theory and practice of online learning (Second). AU Press.

Atsani, K. H. L. G. M. Z. (2020). Transformasi media pembelajaran pada masa Pandemi COVID-19. Al-Hikmah: Jurnal Studi Islam, 1(1), 82-93.

Corbera, E., Anguelovski, I., Honey-Rosés, J., \& Ruiz-Mallén, I. (2020). Academia in the Time of COVID-19: Towards an Ethics of Care. Planning Theory \& Practice, 21(2), 191-199. https://doi.org/10.1080/14649357.2020.1757891

Ernawati, E., \& Mulyono, S. E. (2017). Manajemen pembelajaran program paket C di PKBM bangkit kota semarang. Journal of Nonformal Education, 3(1), 6071. https://doi.org/10.15294/jne.v3i1.8915

Fahmi, M. H. (2020). Komunikasi synchronous dan asynchronous dalam e-learning pada masa pandemic covid-19. Jurnal Nomosleca, 6(2).

Fatayah. (2019). Pengajaran remidi untuk menangani ketidaktuntasan hasil belajar kimia pada materi stoikiometri larutan dan titrasi asam basa. KARANGAN: Jurnal Kependidikan, Pembelajaran, Dan Pengembangan, 01(01).

Fitrianti, L. (2018). Prinsip kontinuitas dalam evaluasi proses pembelajaran. AlIshlah: Jurnal Pendidikan, 10(1), 89-102. https://doi.org/10.35445/alishlah.v10i1.68

Gibson, K. (2020). Bridging the digital divide: Reflections on using WhatsApp instant messenger interviews in youth research. Qualitative Research in Psychology, 0(0), 1-21. https://doi.org/10.1080/14780887.2020.1751902

Gunawan, I. (2011). Evaluasi Program Pembelajaran. Jurnal Pendidikan, 17(1).

House, P., Avenue, M., \& Gate, C. (2020). Online learning, teaching, and education continuity planning for school. International Baccalaureate Organization.

Ilmiani, A. M., Marsiah, M., Rahmah, Y., \& Mubarak, M. R. (2020). Whatsapp Group to Optimize the Mahārah Istimā' Learning During the Covid-19 Pandemic. ALSINATUNA, 6(1), 16-34. https://doi.org/10.28918/alsinatuna.v6i1.2841

Lase, D. (2019). Pendidikan di Era Revolusi Industri 4.0. SUNDERMANN: Jurnal Ilmiah Teologi, Pendidikan, Sains, Humaniora Dan Kebudayaan, 1(1), 28-43. https://doi.org/10.36588/sundermann.v1i1.18

Madden, M. E. (2016). Planning for distance learning: Issues and strategies. Journal of Behavioral and Applied Management, 4(3), 1078.

Miles, M. B., Huberman, A. M., \& Saldana, J. (2019). Qualitative Data Analysis (4th ed.). SAGE Publications.

Mishra, L., Gupta, T., \& Shree, A. (2020). Online teaching-learning in higher education during lockdown period of Covid-19 pandemic. International 
Journal of Educational Research Open, 100012. https://doi.org/10.1016/j.ijedro.2020.100012

Moore, J. L., Dickson-Deane, C., \& Galyen, K. (2011). e-Learning, online learning, and distance learning environments: Are they the same? The Internet and Higher Education, 14(2), 129-135. https://doi.org/10.1016/j.iheduc.2010.10.001

Noval, A., \& Nuryani, L. K. (2020). Manajemen pembelajaran berbasis blended learning pada masa pandemi covid-19 (studi kasus di mas ypp jamanis parigi dan man 1 pangandaran). Jurnal Isema: Islamic Educational Management, 5(2), 201-220. http://dx.doi.org/10.15575/isema.v5i2.10509

Nurgiyantoro, B. (2011). Model Penilaian Otentik dalam Pembelajaran Bahasa. Litera, 10(2).

Octaberlina, L. R., \& Muslimin, A. I. (2020). EFL Students Perspective towards Online Learning Barriers and Alternatives Using Moodle/Google Classroom during COVID-19 Pandemic. International Journal of Higher Education, 9(6), 1. https://doi.org/10.5430/ijhe.v9n6p1

P3GTK Kemendikbud. (2020). Panduan pembelajaran jarak jauh. www.p3gtk.kemdikbud.go.id.

https://p3gtk.kemdikbud.go.id/publikasi/panduan-pembelajaran-jarakjauh-K0012

Ridho, U. (2018). Evaluasi Dalam Pembelajaran Bahasa Arab. An Nabighoh: Jurnal Pendidikan Dan Pembelajaran Bahasa Arab, 20(01), 19-26. https://doi.org/10.32332/an-nabighoh.v20i01.1124

Riqza, M. S., \& Muassomah, M. (2020). Media Sosial untuk Pembelajaran Bahasa Arab pada Masa Pandemi: Kajian Kualitatif Penggunaan WhatsApp pada Sekolah Dasar di Indonesia. Alsina: Journal of Arabic Studies, 2(1), 71-94. http://dx.doi.org/10.21580/alsina.2.1.5946

Rozak, A., \& Albantani, A. M. (2018). Desain perkuliahan bahasa arab melalui google classroom. Arabiyat: Jurnal Pendidikan Bahasa Arab Dan Kebahasaaraban, 5(1), 83-102. https://doi.org/10.15408/a.v5i1.7481

Sewang, A. (2017). Keberterimaan Google Classroom sebagai alternatif Peningkatan Mutu di IAI DDI Polewali Mandar. JPPI Uurnal Pendidikan Islam Pendekatan Interdisipliner), 1(1), 35-46.

Suryati, S. (2017). Sistem manajemen pembelajaran online, melalui e-learning. Ghaidan: Jurnal Bimbingan Konseling Islam Dan Kemasyarakatan, 1(1).

Susanto, G., Suparmi, \& Rahayu, E. Y. (2020). The Emotional Geography of International Students in Online Bahasa Indonesia Learning during the COVID-19 Pandemic. Journal of International Students, 10(S3), 161-179. https://doi.org/10.32674/jis.v10iS3.3205

Tamaji, S. T. (2018). Manajemen Pembelajaran Bahasa Arab. DAR EL-ILMI: Jurnal Studi Keagamaan, Pendidikan Dan Humaniora, 5(1), 107-122. 
Trisiana, A., \& Wartoyo, W. (2016). Desain Pengembangan model pembelajaran Pendidikan Kewarganegaraan melalui ADDIE Model untuk Meningkatkan Karakter Mahasiswa di Universitas Slamet Riyadi Surakarta. PKn Progresif, 11(1), 159079.

Wahid, A. (2018). Integrasi Pendidikan Karakter Dalam Pembelajaran Di Madrasah Diniyah. Tarbawi: Jurnal Pendidikan Islam, 15(1). https://doi.org/10.34001/tarbawi.v15i1.715

Widiasih, R., Hermayanti, Y., \& Ermiati. (2020). International Students' Experience of Studying at Indonesian Universities: Journal of International Students, 10(S3), 24-43. https://doi.org/10.32674/jis.v10iS(2).2710

Yazdi, M. (2012). E-learning Sebagai Media Pembelajaran InteraktifBerbasis Teknologi Informasi. FORISTEK: Forum Teknik Elektro Dan Teknologi Informasi, 2(1).

Yuliani, M., Simarmata, J., Susanti, S. S., Mahawati, E., Sudra, R. I., Dwiyanto, H., Irawan, E., Ardiana, D. P. Y., Muttaqin, \& Yuniwati, I. (2020). Pembelajaran daring untuk pendidikan: Teori dan penerapan. Yayasan Kita Menulis.

Zubaidah, S. (2016). Keterampilan abad ke-21: Keterampilan yang diajarkan melalui pembelajaran. Seminar Nasional Pendidikan Dengan Tema "isu-Isu Strategis Pembelajaran MIPA Abad 21 STKIP Persada Khatulistiwa SintangKalimantan Barat.

\section{Copyright Notice}

Authors retain copyright and grant the journal the right of first publication with the work simultaneously licensed under a Creative Commons Attribution 4.0 International License that allows others to share the work with an acknowledgement of the work's authorship and initial publication in this journal. 
THIS PAGE INTENTIONALLY LEFT BLANK

Jurnal Ilmiah Program Studi Pendidikan Bahasa Arab IAIN Palangka Raya Vol. 9, No. 1 /85-98 Al-Ta'rib | p-ISSN 2354-5887 | e-ISSN 2655-5867 